\title{
Illustrations
}

I. Leaf of the Arian "Silver Bible," 36

2. Remains of beehive hut monastery, 47

3. Abbaye aux Hommes (Men's Abbey), St. Etienne, 55

4. Church of the Holy Savior, Spoleto, 63

5. Lindisfarne Gospel, 66

6. Throne of Charlemagne, Aachen Cathedral, 76

7. St. Martin in Zillis, Switzerland, 82

8. Crusaders' Chapel of the Virgin Mary, Church of the Holy Sepulchre, IO8

9. Abbey of Cluny, I22

IO. Scenes from the Life of Pope Gregory VII, I4I

II. La Grande Chartreuse, I53

I2. Hugh of St. Victor teaching, I6I

I3. Abbey of Fontenay, I67

I4. Fountains Abbey, I68

I5. Abbey of Santa María la Real de Las Huelgas, I72

I6. Expulsion of the Albigensians from Carcassonne, 200

I7. Detail of relief panel, tomb of Saint Dominic Guzman, 2I3

I8. Habit of St. Clare of Assisi, 237

I9. St. Francis of Assisi, 240

20. Church of the Jacobins, 243

2I. Amiens Cathedral, 284

22. Reims Cathedral, 284

23. Pope Innocent III, 289

24. Virgin and Child in Majesty, 303

25. Processional cross, thirteenth century, 304 
26. Crucifix, 1307,305

27. Mont St. Michel, 323

28. Portico of Glory, Santiago de Compostela, 334

29. Reliquary of Ste. Foy, 335

30. Pilgrimage badge of St. Thomas Becket, 338

3I. Chartres Cathedral, 34I

32. Ritual murder of Simon of Trent, 350

33. Palace of the Popes, Avignon, 376

34. Anathema on and deposition of Pope Benedict XIII at Council of Constance, 38I

35. Capture of Jan Hus at Constance, 382

36. Cathedral of Santa Maria del Fiore, Giotto's Bell Tower, and the Baptistery of San Giovanni, Florence, 407

37. Savonarola preaching to the Florentines, 409

38. Cardinal Ximénez's Complutensian Polyglot Bible, 4I6

39. Hildegard of Bingen, 420

40. Late-medieval book of hours, 428

4I. Eucharistic cup and paten probably belonging to St. Francis and followers, 432

\section{Maps and Plans}

I. Germanic pattern of settlement, early sixth century, 35

2. Europe at the time of Gregory the Great, ca. 600, 60

3. Important monasteries of medieval Europe, I65

4. Plan of cruciform church (Chartres) with apsidal chapels, 285

5. Europe ca. I250 with major bishoprics, 296

6. Major pilgrimage sites in western Europe, 330 
This page intentionally left blank 